\title{
The Effect of Some Soil Characteristics on The Hydraulic Conductivity of Soil in Tekirdağ Province
}

\begin{tabular}{l|r}
\hline Research / Araştırma & \\
Received / Gelis Tarihi & Hüseyin SARI \\
27.10 .2017 & \\
$\begin{array}{l}\text { Accepted / Kabul Tarih } \\
10.12 .2017\end{array}$ & Namık Kemal University, Faculty of Agriculture, Department of Soil \\
DOI & Sciences and Plant Nutrition, Tekirdağ-Turkey \\
10.28955/alinterizbd.347179 & e-mail: hsari@nku.edu.tr \\
ISSN 2564-7814 & \\
e-ISSN 2587-2249 &
\end{tabular}

Abstract: In this study, the factors that affect hydraulic conductivity of the soil and their significance was examined. As a field of study, Tekirdağ province was chosen, and sample points were determined by coinciding corine belonging to this city, land use, geology and soil maps in Arcmap program. Samples were collected from 53 different points (Total 187 samples). Samples were taken from 4 different depths $(0-30,30-60,60-90,90-120 \mathrm{~cm})$ from 0 to $120 \mathrm{~cm}$ and then They were analysed by physically and chemically. Hydraulic conductivity measurements were made with Constant Level Permeability device in the laboratory, and the results were figured out according to Darcy's Law. Statistical analysis of the results were made with SPSS and MSTAT-C software programs. Statistically the following results were reached: significant relations were found between hydraulic productivity and clay, bulk density at negative and 1\% level; significant relations were found between hydraulic productivity and sand, specific weight and porosity at positive and $1 \%$ level; insignificant positive relations were found between hydraulic productivity and silt, organic matter; insignificant negative relations were determined between hydraulic and lime, $\mathrm{pH}$, salt; and significant relations at $1 \%$ level were found in the interactions made between hydraulic productivity and land use.

Keywords: Hydraulic conductivity, texture, permeability, Tekirdağ

\section{Tekirdağ İli Topraklarında Bazı Toprak Özelliklerinin Topraktaki Hidrolik İletkenliğe Etkisi}

Öz: Yapılan bu çalışmada toprağın hidrolik iletkenliğine etki eden faktörler ve bunların önem durumları irdelenmiştir. Çalışma alanı olarak Tekirdağ il sınırları seçilmiş olup bu ile ait corine, arazi kullanımı, jeoloji ve toprak haritaları Arcmap programında çakıştırılarak örnek noktaları belirlenmiș ve 53 farklı noktadan örnek alınmıştır. 0-120 cm de 4 farklı (0-30, 30-60, 60-90, 90-120 cm) derinlikten alınan örnekler de fiziksel ve kimyasal analizler yapılmıştır. Hidrolik iletkenlik ölçümleri laboratuarda sabit seviyeli permeabilite cihazı ile ölçülmüş olup sonuçları Darcy Yasasına göre hesaplanmıştır. Sonuçların istatistiki analizi SPSS ve MSTATC programları ile yapılmıștır. Yapılan istatistiki çalıșmada, hidrolik iletkenlik ile kil ve hacim ağırlığı arasında, negatif ve \% 1 düzeyinde önemli; hidrolik iletkenlik ile kum, tane yoğunluğu ve porozite arasında pozitif ve \% 1 düzeyinde önemli; hidrolik iletkenlik ile silt, organik madde arasında pozitif ve önemsiz; hidrolik iletkenlik ile kireç, $\mathrm{pH}, \mathrm{EC}$ arasında negatif ve önemsiz, hidrolik iletkenlik ile arazi kullanımı arasında yapılan interaksiyonlar da ise \% 1 düzeyinde önemli ilişkiler bulunmuștur.

Anahtar Kelimeler: Hidrolik iletkenlik, tekstür, geçirgenlik, Tekirdă̆

\section{INTRODUCTION}

Movement of water in the soil is of great importance in a lot of ways in rural and urban life. Access of water into the soil and its movement towards plant roots, its flow into drainages and wells, its evaporation from earth's surface are just a few circumstances in which water's movement speed plays a significant role. Soil characteristics determining ground water flow system, water conductivity and water retention are characteristic features of the soil. Soil's water conductivity is a measurement of its capacity to permeate water. Water retention feature, on the other hand, is an expression of soil's water 
storage capacity. These features determine soil-water system's response to the boundary conditions it Alintert is exposed to and are usually referred to as soil's hydraulic features (Klute 1986).

Soil's water conductivity plays an important role in the effective use of water resources, as well. In agriculture, it is important to give the plant as much water as it needs. This is because, in addition to excessive water consumption, a loss of nutrients and soil due to washing and moving are observed in surface irrigation. This impoverishes the soil in nutritional elements and organic materials and might lead to economic loss through either a decrease in the amount of crops grown or overuse of fertilizers due to the loss of nutritional elements that has arisen.

This study was carried out to reveal the effects of different soil management applications together with soil's physical or chemical properties on its hydraulic conductivity. Furthermore, clay, silt, sand, particle density, bulk density, lime, $\mathrm{pH}, \mathrm{EC}$ (electricity conductivity), organic materials, porosity and aggregate stability properties of the Tekirdağ province were mapped, and attempts at showing the distribution thereof across regions were made.

\section{MATERIAL AND METHOD}

\section{Material}

The study area is Tekirdag province which situated on the Thracian Peninsula in Northwestern Turkey (coordinates: $\mathrm{N} 40^{\circ} 32^{\prime}-41^{\circ} 34^{\prime}$ and E $26^{\circ} 37^{\prime}-28^{\circ} 11^{\prime}$ ). Neighboring Kurklareli in the north, Edirne in the west, Çanakkale in the southwest, and Istanbul in the east, the provincial land is surrounded by the Sea of Marmara from the south and the Black Sea from the northeast (Figure 1).

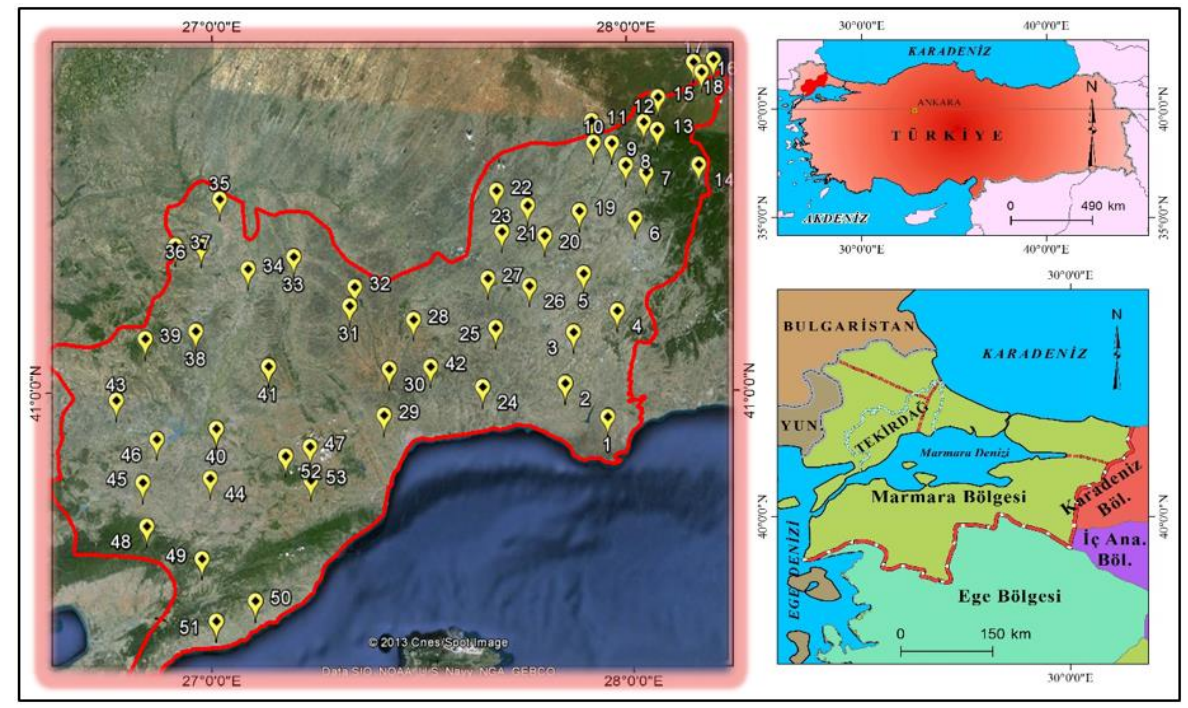

Figure 1. Location map of Tekirdag province

The provincial land, which consists mainly of rocks of Strandjha Massive origin, also contains various rock groups from different eras. The tectonic formation of the field came into being via North Anatolian Fault and its extensions that are present in this area. The highest spot of the province where miscellaneous landforms are defined is Ganos Mountain $(924 \mathrm{~m})$ while its lowest spot is the sea level. In general, the provincial land is dissected by streams, and it has a southward-sloping tableland characteristic (Özşahin, 2015a: 7). Well-developed bottomlands are also deposited in the coastal parts of the province and valley bottoms of the streams. Four different climate types, Black Sea Climate, Mediterranean Climate, Continental Climate, and Marmara Transition Climate can be identified in Tekirdag although not all of them completely display their characteristic features (Atalay, 2013: 515).The most prominent stream of Tekirdag province is Ergene River, which flows through the north of the provincial land. Other significant streams are Hayrabolu, Besiktepe, Corlu, Isıklar, and Gölcük rivers (Gürpınar, 1994:76-78). From the provincial borders that contain samples from artificial lakes, water is obtained primarily for irrigation but also for drinking and utility. In light of the information obtained by earthworks and land surveys conducted across Tekirdag province, 6 soil orders were identified according to the Soil Taxonomy. These were Entisols, Alfisols, Inceptisols, Mollisols, Vertisols, and Andisols (Ekinci, 1990: 43). Dependent on the prominent climate type, the natural 
vegetation cover is arid forest in the inner area, sub-humid forest in the coastal areas, and humid forest Alinteri in the highlands (Dönmez, 1990: 223).

\section{Method}

Provincial borders of Tekirdağ being determined as the study area, attention was paid to the selection of different types of soil according to the soil maps of the province. Soil map digitised as the Soil Group map prepared by the General Directorate of Rural Services was used (Anonymous 1985). Distribution of locations, from which soil samples were taken, by soil groups is given in Figure 3.4. Hydraulic conductivity measurements were performed over a total of 374 soil samples, 187 of which were disturbed and the other 187 intact, from 53 different locations and 4 different levels of depth. Samples being taken from depths of 0-30, 30-60, 60-90, 90-120 cm in the designated soils, depth level of $120 \mathrm{~cm}$ could not be reached at some locations due to low profile depth. Intact soil samples were taken from sample locations for hydraulic conductivity measurement, and disturbed soil samples were taken for analysis. Both samples were brought into the laboratory. After the disturbed soil samples brought to the laboratory were dried and sifted through a 2-mm sieve, related analysis was carried out. Intact samples, on the other hand, were subjected to hydraulic conductivity analysis.

\section{Methods used in the laboratory studies}

Soil specimens taken from the research area were dried in the laboratory, then they were ground and sieved with $2 \mathrm{~mm}$ pore sized sieve and became ready for the analyses.

The following analyzes were made in the soil.

1- Soil moisture; samples were stored at $105^{\circ} \mathrm{C}$ in a drying oven at constant temperature.

2- Soil reaction $(\mathrm{pH})$ : it was determined by using a $\mathrm{pH}$ meter with glass electrode in a $1 / 2.5$ ratio soil-water suspension (Jackson 1958).

3- EC: Electrical conductivity was determined with Wheatstone Bridge conductivity instrument in a 1 / 2.5 ratio soil-water suspension (Richards 1954).

4- Lime; It was determined volumetrically by the method of calcimetry (Sağlam 2008).

5- Grain size distribution (Texture); It was determined by using Bouyoucos hydrometer method (Bouyoucos 1953). Texture triangles were used in the naming of texturing classes (Anonymous 1993).

6- Organic matter (\%); It was determined by the Smith-Weldon method and the Organic C method (Sağlam 2008).

7- Particle density; It was made by using picnometer method in deteriorated soil samples (Black 1965).

8- Bulk density: It was carried out with the cylinder method (Black 1965).

9- Porosity: it was determined by calculation of dry bulk density and particle density (Black 1965).

10- Statistics; Hydraulic conductivity is considered as the main factor in the study using the data obtained in the research, correlation and standard tests (Düzgüneş ve ark. 1987).

11- Hydraulic conductivity: it was determined with the method given in Tüzüner (1990).

Fixed Water Level Permeability Device; Under a hydraulic load, it constitutes the basic principle of the method of measuring the volume of water passing through the pores of a soil sphere of a certain thickness per unit volüme

\section{RESULTS AND DISCUSSION}

The results of the analysis are in wide ranges which will positively affect the statistical results. The following results were found in the analyzes made. Clay; 9-70\%, silt; $2-52 \%$, sand; 3-88\%, grain density; 2.25-2.94 gr/cm3, dry volume weight; 0.88-1.78 gr/cm3, lime; 0-24\%, pH; 5,35-8,97, ec: 20 $758 \mu \mathrm{s} / \mathrm{cm}$, organic matter; $0.03-15.04 \%$, porosity; 29.29-64.37

\section{Hydraulic Conductivity}

When depths were analysed, it was observed that the average hydraulic conductivity value varied from $0,52-3,58 \mathrm{~cm} /$ hour. The highest hydraulic conductivity content was identified at the depth of 0 $30 \mathrm{~cm}$, followed by $30-60 \mathrm{~cm}$. As for the lowest hydraulic conductivity value, it was set at a depth of 90- $120 \mathrm{~cm}$. 
Table 1. Standard tests for hydraulic conductivity

\begin{tabular}{lllllll}
\hline Depth $(\mathbf{c m})$ & Min & Maximum & Variance & S. Deviation & Sx & VK (\%) \\
\hline 30 & 0 & 18,15 & 25,0156 & 5,0016 & 0,6936 & 153,9944 \\
\hline 60 & 0 & 10,03 & 3,2888 & 1,8135 & 0,2565 & 256,5784 \\
\hline 90 & 0 & 7,67 & 1,6520 & 1,2853 & 0,1983 & 231,6850 \\
\hline 120 & 0 & 7,86 & 2,6924 & 1,6409 & 2,2814 & 246,2007 \\
\hline
\end{tabular}

When the analysis results are examined, the water conductivity decreases as they get deeper. Southard and Boul (1988) found that the hydraulic conductivities were the highest in the top soil. They also claimed that the upper soil is exposed to many human activities, because of this there is much more soil airing at the top soil.

Clay

When depths were analysed, it was observed that the average clay value varied from $34,83 \%$ to $41,91 \%$. The highest clay content was identified at the depth of $60-90 \mathrm{~cm}$, followed by $90-120 \mathrm{~cm}$. As for the lowest clay value, it was set at a depth of 0-30 cm. Considering the correlations between hydraulic conductivity and clay, relationships were observed at negative and significant levels.

Table 2. Correlations of clay values (r)

\begin{tabular}{lcc}
\hline Correlation by depths $(\mathbf{r})$ & & General correlation $(\mathbf{r})$ \\
\cline { 1 - 2 } Depth $(\mathbf{c m})$ & Correlation & $-0,408^{* *}$ \\
\hline $0-30$ & $-0,325^{* *}$ & \\
\hline $30-60$ & $-0,358^{* *}$ & \\
\hline $60-90$ & $-0,373^{* *}$ & \\
\hline $90-120$ & $-0,373^{*}$ & \\
\hline
\end{tabular}

Silt

When depths were analysed, it was observed that the average silt value varied from $19,46 \%$ to $23,44 \%$. The highest silt content was identified at the depth of $0-30 \mathrm{~cm}$, followed by $30-60 \mathrm{~cm}$. As for the lowest silt value, it was set at a depth of 90-120 cm. Considering the correlations between hydraulic conductivity and silt, relationships were observed at negative and insignificant levels.

Table 3. Correlations of silt values (r)

\begin{tabular}{lcc}
\hline Correlation by depths $(\mathbf{r})$ & & General correlation $(\mathbf{r})$ \\
\hline Depth $(\mathbf{c m})$ & Correlation & $-0,134$ \\
\hline $0-30$ & $-0,133 \mathrm{~ns}$ & \\
\hline $30-60$ & $0,199 \mathrm{~ns}$ & \\
\hline $60-90$ & $-0,022 \mathrm{~ns}$ & \\
\hline $90-120$ & $-0,174 \mathrm{~ns}$ & \\
\hline
\end{tabular}

Sand

When depths were analysed, it was observed that the average sand value varied from $38,13 \%$ to $41,51 \%$. The highest sand content was identified at the depth of $0-30 \mathrm{~cm}$, followed by $30-60 \mathrm{~cm}$. As for the lowest sand value, it was set at a depth of $60-90 \mathrm{~cm}$. Considering the correlations between hydraulic conductivity and sand, relationships were observed at positive and significant levels.

Table 4. Correlations of sand values (r)

\begin{tabular}{lcc}
\hline Correlation by depths $(\mathbf{r})$ & & General correlation $(\mathbf{r})$ \\
\cline { 1 - 2 } Depth $\mathbf{( c m})$ & Correlation & $0,261^{* *}$ \\
\hline $0-30$ & $0,338^{* *}$ & \\
\hline $30-60$ & $0,175 \mathrm{~ns}$ & \\
\hline $60-90$ & $0,303^{*}$ & \\
\hline $90-120$ & $0,406^{* *}$ & \\
\hline
\end{tabular}




\section{Particle Density}

When depths were analysed, it was observed that the average grain density value varied from 2,59$2,63 \mathrm{gr} / \mathrm{cm}^{3}$. The highest grain density content was identified at the depth of $90-120 \mathrm{~cm}$, followed by $30-60 \mathrm{~cm}$. As for the lowest grain density value, it was set at a depth of $60-90 \mathrm{~cm}$. Considering the correlations between hydraulic conductivity and grain density, relationships were observed at positive and significant levels.

Table 5. Correlations of grain density values (r)

\begin{tabular}{lcc}
\hline Correlation by depths $(\mathbf{r})$ & & General correlation $(\mathbf{r})$ \\
\cline { 1 - 2 } Depth $(\mathbf{c m})$ & Correlation & $0,251^{* *}$ \\
\hline $0-30$ & $0,465^{* *}$ & \\
\hline $30-60$ & $0,119 \mathrm{~ns}$ & \\
\hline $60-90$ & $0,431^{* *}$ & \\
\hline $90-120$ & $0,028 \mathrm{~ns}$ & \\
\hline
\end{tabular}

\section{Bulk Density}

When depths were analysed, it was observed that the average bulk density value varied from 1,39-1,47 $\mathrm{gr} / \mathrm{cm}^{3}$. The highest bulk density content was identified at the depth of $60-90 \mathrm{~cm}$, followed by $30-60$ $\mathrm{cm}$. As for the lowest bulk density value, it was set at a depth of $30-60 \mathrm{~cm}$. Considering the correlations between hydraulic conductivity and bulk density, relationships were observed at negative and significant levels.

Table 6. Correlations of bulk density values (r)

\begin{tabular}{lcc}
\hline Correlation by depths $(\mathbf{r})$ & & General correlation $(\mathbf{r})$ \\
\hline Depth $(\mathbf{c m})$ & Correlation & $-0,280^{* *}$ \\
\hline $0-30$ & $-0,168 \mathrm{~ns}$ & \\
\hline $30-60$ & $-0,294^{*}$ & \\
\hline $60-90$ & $0,038 \mathrm{~ns}$ & \\
\hline $90-120$ & $-0,005 \mathrm{~ns}$ & \\
\hline
\end{tabular}

\section{$\mathrm{CaCO}_{3}$}

When depths were analysed, it was observed that the average $\mathrm{CaCO}_{3}$ value varied from $2,46 \%$ to $3,38 \%$. The highest $\mathrm{CaCO}_{3}$ content was identified at the depth of $0-30 \mathrm{~cm}$, followed by $60-90 \mathrm{~cm}$. As for the lowest $\mathrm{CaCO}_{3}$ value, it was set at a depth of $90-120 \mathrm{~cm}$. Considering the correlations between hydraulic conductivity and $\mathrm{CaCO}_{3}$, relationships were observed at negative and insignificant levels.

Table 7. Correlations of $\mathrm{CaCO}_{3}$ values (r)

\begin{tabular}{lcc}
\hline Correlation by depths $(\mathbf{r})$ & & General correlation $(\mathbf{r})$ \\
\cline { 1 - 2 } Depth $(\mathbf{c m})$ & Correlation & $-0,71$ \\
\hline $0-30$ & $-0,105 \mathrm{~ns}$ & \\
\hline $30-60$ & $0,154 \mathrm{~ns}$ & \\
\hline $60-90$ & $0,042 \mathrm{~ns}$ & \\
\hline $90-120$ & $-0,029 \mathrm{~ns}$ & \\
\hline
\end{tabular}

pH

When depths were analysed, it was observed that the average $\mathrm{pH}$ value varied from 7,2-7,35. The highest $\mathrm{pH}$ content was identified at the depth of 30-60 cm, followed by $0-30 \mathrm{~cm}$. As for the lowest $\mathrm{pH}$ value, it was set at a depth of $90-120 \mathrm{~cm}$. Considering the correlations between hydraulic conductivity and $\mathrm{pH}$, relationships were observed at negative and insignificant levels. 
Table 8. Correlations of $\mathrm{pH}$ values (r)

\begin{tabular}{lcc}
\hline Correlation by depths $(\mathbf{r})$ & & General correlation $(\mathbf{r})$ \\
\cline { 1 - 2 } Depth $(\mathbf{c m})$ & Correlation & $-0,001$ \\
\hline $0-30$ & $-0,027 \mathrm{~ns}$ & \\
\hline $30-60$ & $0,144 \mathrm{~ns}$ & \\
\hline $60-90$ & $0,201 \mathrm{~ns}$ & \\
\hline $90-120$ & $0,234 \mathrm{~ns}$ &
\end{tabular}

\section{EC (Electricity Conductivity)}

When depths were analysed, it was observed that the average electricity conductivity value varied from $143,85-168,31 \mu \mathrm{S} / \mathrm{cm}$. The highest electricity conductivity content was identified at the depth of $0-30 \mathrm{~cm}$, followed by $90-120 \mathrm{~cm}$. As for the lowest electricity conductivity value, it was set at a depth of $60-90 \mathrm{~cm}$. Considering the correlations between hydraulic conductivity and electricity conductivity, relationships were observed at negative and insignificant levels.

Table 9. Correlations of EC values (r)

\begin{tabular}{lcc}
\hline Correlation by depths $(\mathbf{r})$ & & General correlation $(\mathbf{r})$ \\
\cline { 1 - 2 } Depth $\mathbf{( c m})$ & Correlation & $-0,040$ \\
\hline $0-30$ & $-0,318^{*}$ & \\
\hline $30-60$ & $0,158 \mathrm{~ns}$ & \\
\hline $60-90$ & $-0,017 \mathrm{~ns}$ & \\
\hline $90-120$ & $0,008 \mathrm{~ns}$ & \\
\hline
\end{tabular}

\section{Organic Matter}

When depths were analysed, it was observed that the average organic matter value varied from $1,30 \%$ to $2,70 \%$. The highest aggregate stability content was identified at the depth of $0-30 \mathrm{~cm}$, followed by $30-60 \mathrm{~cm}$. As for the lowest aggregate stability value, it was set at a depth of $60-90 \mathrm{~cm}$. Considering the correlations between hydraulic conductivity and organic matter, relationships were observed at positive and insignificant levels.

Table 10. Correlations of organic matter values (r)

\begin{tabular}{lcc}
\hline Correlation by depths $(\mathbf{r})$ & & General correlation \\
\cline { 1 - 2 } Depth $(\mathbf{c m})$ & Correlation & \\
\hline $0-30$ & $0,084 \mathrm{~ns}$ & 0,053 \\
\hline $30-60$ & $0,114 \mathrm{~ns}$ & \\
\hline $60-90$ & $0,249 \mathrm{~ns}$ & \\
\hline $90-120$ & $0,048 \mathrm{~ns}$ & \\
\hline
\end{tabular}

\section{Porosity}

When depths were analysed, it was observed that the average aggregate stability value varied from $43.68 \%$ to $46.14 \%$. The highest aggregate stability content was identified at the depth of $0-30 \mathrm{~cm}$, followed by $30-60 \mathrm{~cm}$. As for the lowest aggregate stability value, it was set at a depth of $60-90 \mathrm{~cm}$. Considering the correlations between hydraulic conductivity and aggregate stability, relationships were observed at positive and significant levels.

Table 11. Correlations of porosity values (r)

\begin{tabular}{lcc}
\hline Correlation by depths $(\mathbf{r})$ & & General correlation $(\mathbf{r})$ \\
\cline { 1 - 2 } Depth $(\mathbf{c m})$ & Correlation & $0,358^{* *}$ \\
\hline $0-30$ & $0,331^{* *}$ & \\
\hline $30-60$ & $0,336^{*}$ & \\
\hline $60-90$ & $0,143 \mathrm{~ns}$ & \\
\hline $90-120$ & $0,020 \mathrm{~ns}$ & \\
\hline
\end{tabular}


Physical and chemical properties of the soil have a direct or indirect effect on soils' hydraulic ${ }^{\circ}$

conductivity. For example, whereas bulk density based on texture and changes occurring in porosity affect hydraulic conductivity, organic materials have an effect on porosity and therefore on bulk density which, in turn, affects hydraulic conductivity. Accordingly, soil texture is considered to be the most significant factor in hydraulic conductivity. Bahtiyar (1996) stated that hydraulic conductivity usually follows the sandy>loamy>clayey pattern in soils and pointed out that, rather than the total pore size, hydraulic conductivity was identified based on the proportional amount of macro pores within the pore size distribution and continuous formation of canaliculuses by them. In this regard, he pointed out that texture, structure, amount of organic materials, type of clay minerals and type and concentration of electrolytes in the soil solution can be listed among the main soil features affecting hydraulic conductivity.

Amounts of organic materials in the research soils had a positive effect on hydraulic conductivity values and increased the hydraulic conductivity of the soils. However, such increase in the hydraulic conductivity of the soils was not considered statistically significant. Not only do organic materials increase the water retention capacity in the soil but they also have a positive effect on the structure. They increase the number of macro pores in the soils, leading to an increase in hydraulic conductivity. Y1lmaz and Alagöz (2008) state that high amounts of organic materials in soils increase porosity, hydraulic conductivity and water retention capacity.

The effect of lime values of the soils on hydraulic conductivity was found to be statistically insignificant. It was determined that the effect of lime content on hydraulic conductivity might be due to its rehabilitating effect on the structure and that there is not a direct relationship. As a matter of fact, in the study they carried out, Şeker and Aydın (2004) stated that there is not a relationship between hydraulic conductivity and lime.

$\mathrm{EC}$ and $\mathrm{pH}$ values of the research soils did not have a significant effect on hydraulic conductivity. Such effect was found to be statistically insignificant, too. Salt content might be expected to have a negative effect on hydraulic conductivity as it increases the sodium content of soils, leading to dispersion. However, as the salt levels of the soils are not at a level that disturbs the structure, salt content was not observed to have any effects on hydraulic conductivity. According to Dane and Klute (1977), concentration and composition of dissolved salts may have a certain effect on hydraulic conductivity as it might lead to the dispersion and expansion of soil particles depending on the characteristics and amounts of replaceable cations. Horn (1971) predicates replaceable sodium percentage and total salt concentration among the main factors affecting hydraulic conductivity.

\section{CONCLUSION}

According to the research results, almost all of the factors investigated have an effect on hydraulic conductivity. Considering the general results, the importance level of clay, sand, particle density, bulk density and porosity being $1 \%$, they stand out as the factors affecting hydraulic conductivity the most. Other factors such as silt, $\mathrm{CaCO} 3, \mathrm{pH}, \mathrm{EC}$ and organic materials have insignificant effects. The statistics carried out in the layers imply the same. However, such level of significance might differ across levels. The reason for this can be explained by the distribution of the samples belonging to that layer.

When general hydraulic conductivity distribution is examined, it is seen that while hydraulic conductivity decreases as you proceed towards deeper layers in some locations, it increases in others. Hydraulic conductivity increases near coastal areas or in the deeper layers of alluvial accumulations due to the increase in the amount of sand. In other places, on the other hand, hydraulic conductivity decreases in the ordinary course of things as the clay content increases and structure formation decreases towards the bottom layers.

High underground water creates many direct or indirect negative effects in agricultural areas. Whereas drainage systems are established in rainfall zones in the first place to remove extra water, need for drainages has become inevitable in irrigated farming areas due to an increase in the amount of irrigated areas and due to secondary salinization, as well. Blockage of vehicle traffic or agricultural processes on the land, late annealing of soils, soil cultivation and agricultural works' becoming more difficult, delays in sowing times, limitation of plant's root zone due to the height of ground water level and impairment of plant roots left in water due to airlessness can be listed among the disadvantages of drainages. Decreases in the amount of crops are observed due to the aforementioned factors. Moisture status of the soil changes based on the position of the ground water. So, whereas poor growth is 
observed in plants in undrained soil due to small root areas resulting from a high ground water level, a Alintert full-grown plant based on a developed root system is observed in drained soil.

Salts dissolved in the ground water may rise up to the root zone of the plant and sometimes even up to the soil surface through capillary rise. Salt concentration of ground water increases as a result of evaporation of water and its absorption by plants. In this way, salts may accumulate in the soil and reach levels that can harm plants. Said events are more common in regions with hot and dry summers and level grounds. On the other hand, reduction of the ground water level to deeper levels may lead to an increase in the water needs of plants. Water shortages in summer and reductions in crops due to corresponding water shortages might be observed in some areas especially in coarse textured soils with low capillary rise (Bahceci 2009).

Soils with problematic physical and chemical structures must be improved. Such factors as drainage, aeration, water retention are very important in soil improvement. Circumstances not suitable for plant development may occur on clayey earth as hydraulic conductivity will be low. Therefore, drainage systems enabling water flow need to be built. On sandy earth, on the other hand, barnyard manure and organic wastes must be dug in to increase the water retention capacity of the soil. In this way, an atmosphere that is suitable for the vegetable to grow can be established.

Considering the hydraulic conductivity map of the Tekirdağ province, impermeable layers are not encountered very often at a depth of $0-30 \mathrm{~cm}$. Hydraulic conductivity values are high in coastal areas due to sand dunes. In order to increase the water retention capacity of soil in these areas, such practices as green manure and barnyard manure can be carried out. However, when depths of 30-60 $\mathrm{cm}$ are examined, it is observed that the hydraulic conductivity value in the area between Çorlu and Çerkezköy is very low. In this area, an atmosphere that is unfavourable for plant development can be encountered due to the fact that water does not proceed deeper down the layers. Considering the depth of $60-90 \mathrm{~cm}$ in the same area, it can be observed that such low-permeable area does not exist here. The area that remains in between can be tilled with a subsoiler rendering such layer permeable as well.

\section{ACKNOWLEDGEMENT}

This paper is based on a PhD study titled "The Effect of Some Land Characteristics on The Hydraulic Conductivity of Soil İn The City of Tekirdağ" This thesis study was supported by NKUBAP.

\section{REFERENCES}

Anonymous (1985). Sayısal Toprak Haritası. Köy Hizmetleri Genel Müdürlüğü. Ankara

Anonymous (1993). Soil Survey Laboratory Methods and Procedures For Collecting Soil Samples. Soil Survey Investigation Report No:1 USDA. Washington DC., USA.

Atalay, İ., 2013. Uygulamalı Klimatoloji. 2. Bask1, Meta Basım Matbaacılık Hizmetleri, İzmir.

Bahçeci. İ., 2009. Drenaj Mühendisliği. Şanlıurfa. http://ziraat.harran.edu.tr/tys/drenmh1.pdf (17.07.2013).

Bahtiyar, M., 1996. Toprak Fiziği. Trakya Üniversitesi Tekirdağ Ziraat Fakültesi Yayın No:260 Ders Kitab1 No:31 S:251. Tekirdağ

Black, C.A., 1965.Methods of Soil Analysis. Part I.American Society of Agronomy, Agronomy No:9.

Bouyoucos, G. J., 1953. An improved type of soil hydrometer. Soil Sci

Dane J H A. Klute, 1977. Salt Effeets on the Hydraulic Properties of a Swelling Soil. Soil Sci. Soc. Am. J., 41: 1043-1049.

Dönmez, Y., 1990. Trakya'nın Bitki Coğrafyası. Genişletilmiş İkinci Baskı, İstanbul: İstanbul Üniversitesi Yayınları No: 3601, Coğrafya Enstitüsü Yayınları No: 51.

Düzgüneş O, Kesici T, Kavuncu O, Gürbüz F. (1987). Araştırma ve Deneme Metotları (İstatistik Metodları II). A.Ü. Ziraat Fakültesi Yay. No.1021, Ankara, 295s.

Ekinci, H., 1990. Türkiye Genel Toprak Haritasının Toprak Taksonomisine Göre Düzenlenebilme Olanaklarının Tekirdağ Bölgesi Örneğinde Araştırılması. Yayınlanmamış Doktora Tezi. Adana: Çukurova Üniversitesi Fen Bilimleri Enstitüsü Toprak Anabilim Dalı.

Gürpınar, E., 1994. Bir Çevresel Analiz Örneği Trakya. İstanbul: Der Yayınları.

Horn, M. E., 1971. Estimating Soil Permeability Rates, Jour. Of the Ir. And Drainage Div., Ir 2, ASCE., 97:263274.

Jackson, M. L., 1958. Soil Chemical Analysis. Prentice Hail Inc. Englewood Cliffs,N.J.

Kemper, W. D., Koch, E. J., 1966. Aggregate Stability of Soils from Western United States and Canada. U.S. Depertmant of Agriculture Tech. Bull. No:1355

Klute, A., 1986. Hydraulic conductivity and diffusivity : laboratory methods, in Methods of Soil Analysis, Part 1 (A. Klute, Ed.), Am. Soc. Agron., Madison, WI.

Richards, L. A., 1954. Diagnosis and Improvement of Saline and Alkali Soils. USDA.Handbook, No:60. USA.

Sağlam, M. T., 2008. Toprak ve Suyun Kimyasal Analiz Yöntemleri. Trakya Üniversitesi Tekirdağ Ziraat Fakültesi Yayın No: 189. Yardımcı Ders Kitabı No: 5. Tekirdağ. 
Southard, R. J. and Buol, S. W., 1988. Subsoil saturated hydraulic conductivity in relation to soil properties in the North Carolina coastal plain. Soil Sci. Soc. Am. J. 52 ; 1091-1094.

Şeker, G., Aydın, G., 2004. Büyük Menderes Havzasında Yaygın İki Toprak Serisinde Toprak Sıkışması Kaynaklı Bazı Fiziksel Özelliklerinin Değerlendirilmesi. Adnan Menderes Üniversitesi Ziraat Fakültesi Dergisi. 1(1) S:47-52 Aydın.

Tüzüner, A., 1990. Toprak ve Su Analizleri Laboratuarları El Kitabı. Köy Hizmetleri Genel Müdürlügü Yayınları, Ankara.

Özşahin, E., 2015. Şehir ve Toprak Arasındaki İlişkinin Coğrafi Yaklaşımla İncelenmesi: Tekirdağ Şehri Örneği. Turkish Studies-International Periodical For the Languages, Literature and History of Turkish or Turkic, Volume: 10/3, Winter 2015, p.: 733-758.

Yilmaz, E. ve Alagoz, Z., 2008. Organik Madde Toprak Suyu İlişkisi, Türk Bilimsel Derlemeler Dergisi, cilt.1, ss.15-21. 